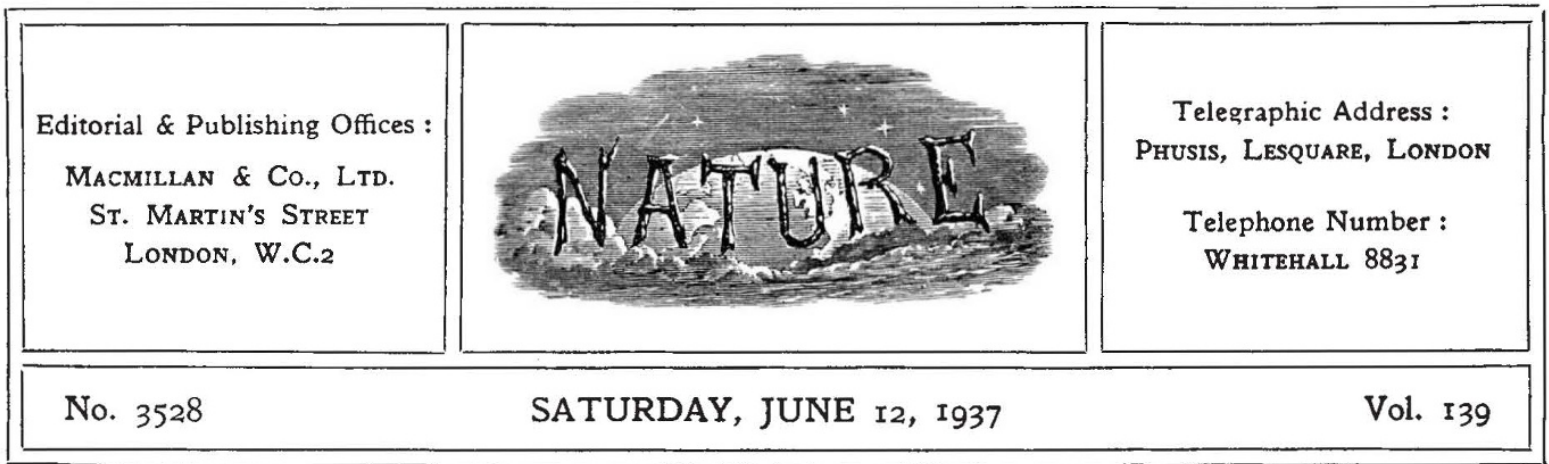

\title{
Science and Peace
}

$\mathrm{I}^{\mathrm{N}}$ the remarkable differences between the world to-day and that of a century ago, the good changes and the evil are in the last resort due mainly to the use or misuse of scientific discovery. Men of science are, of course, not the sole agents in the transformation; their work is applied by others, under the direction of industrialists and Governments, for private gain or for the public good as judged by statesmen and administrators.

Until lately, the average man of science was scarcely more interested in the uses to which his work was put than is the ostrich in the fate of the eggs that she lays. There will always be scientific workers whose interests seem far removed from ordinary human affairs; but the activities of an increasing proportion of men of science are closely linked with social purposes. Many of these can work with good heart in full confidence that the fruits of their labours increase the health and happiness of mankind ; but there is a darker side to the picture, since through science the horrors and waste of war have been greatly intensified. The result is that some people think that the only way to save civilization is to suppress further advances in scientific knowledge.

Responsibility for the deplorable growth of destructive forces cannot, however, be accepted by men of science except as citizens. Throughout recorded history there has been war, and the captains and the kings have always sought to increase their military strength by the inventions and the science of their time. The change in our day is not fundamental, but lies only in the much greater effectiveness with which the old purposes are pursued, through the application of modern scientific method and resources. From the military point of view, organized scientific effort meets with the same astonishing success as when applied to peaceful ends; but the result for mankind is to extend enormously the burden of fear and the potential human suffering through war. Indeed, ever since the Great War, this suffering has been not only potential but actual, as recently in Abyssinia and now in Spain.

The Founder of Christianity asked from the Cross forgiveness for those who set Him there, "for they know not what they do". The cross of war laid upon mankind is due, like that other Cross in Jerusalem, to the moral and intellectual frailty of man-to the craft of a few who are deeply evil ; to the folly and weakness of others among the great, who are not lacking in goodwill ; to the passions and tumult of the multitude. Perhaps the share of science in this modern crucifixion may be compared with the work of the soldiers who then drove in the nails and raised high the crosses.

Were these soldiers worse than other soldiers? Was not the Government and nation that made them soldiers, and assigned their tasks to them, more responsible than they for that evil ? In like manner, are those scientific workers who are directly working for military ends to be regarded as worse than other men of science? Surely the chief responsibility lies with the community at large; and in proportion to his single-minded simplicity, the militarized man of science, like the common soldier, is to be honoured for the faithful following of his vocation.

Many minds, however, cannot find rest in simple obedience to authority, in simple national patriotism. The principle of the settlement of disputes by war is increasingly questioned by the mind and conscience of man, and not least among men of 
science. Many fair-seeming bubbles have been burst, and recognized for the hollow, puffed-out things that they are: the famous Oxford resolution on fighting for king and country was symptomatic of this. Of course, if Britain should become involved in war, the youth of Oxford would fight; but among them and the rest of the soldiers there would be a larger proportion than in any previous war, who from the outset realized the futility, the colossal folly of war. Even in Germany, with all its unchallenged internal propaganda, it is not too easy to resurrect the old 'Heldentum' nonsense, which many German ex-soldiers hoped had been cast into limbo for ever.

Already in the time of the Great War the prostitution of science to warfare was deeply felt by many British men of science, some of whom refused altogether to participate either as soldiers or as scientific workers. The same attitude would again be taken by many, should we be cursed by another war; even in the present time of uneasy peace, the activity in rearmament is renewing in the minds of many men of science the same tension of feeling, the same problems of conscience. Such scruples, sincerely held, claim at least the same measure of public consideration and respect as they received in Britain during the Great War. For such men there is often no choice whether they shall or shall not refuse war-service, scientific or otherwise; like Luther on a famous occasion, "they can no other".

Most men of science will know outstanding examples, among their colleagues, of men who so refused in the Great War, and, by our national wisdom, were spared the penalties that in other countries might have led to their death, by direct act or by obloquy and torment leading to suicide. Many such men have, in the years since then, rendered distinguished service to the community; their work, and that of many lesser men who followed the same course, has enriched the nation, and been rendered with loyal recognition of the toleration extended to them by their fellowcitizens during a time of great national stress.

To the main body of men of science, however, military preparations, and scientific co-operation in them, seem in the existing state of the world a necessary, though regrettable, measure. It is important that there should be mutual respect and understanding between this majority, and their colleagues who are extreme pacifists-the larger group standing by the minority, to protect them against victimization, and the minority co-operating wherever possible with their fellows, and respecting in them their loyalty to their duty as they perceive it.

Should this duty end, however, with the performance of their special technical functions? Does there not rest upon men of science as a body a responsibility for the promotion of peace, and peaceful methods of international adjustment, beyond that which already attaches to them as citizens? Their special outlook, education, training and gifts seem to involve this.

In the first place, scientific workers are better able than most men to reflect with knowledge upon the evolution of man, and to realize what immense conquests have already been made over ignorance, weakness and evil. They can in some measure review the progress of man in social organization, and envisage great improvements still to come, realizing that even to-day unity in government may be maintained, as in Canada, despite enduring differences of race, religion, language and traditions among the people. They know that wider loyalties can develop and become paramount over a hierarchy of narrower loyalties. They have, therefore, ground for good hope, since so much has been achieved by steps largely unconscious or groping, that far more can yet be done by conscious and well-chosen effort.

Secondly, they have long been accustomed to international co-operation, without which the state of science itself would still be relatively primitive. They can, therefore, well judge how fruitful would be the adoption of a similar policy in the social and economic sphere, even if military budgets continued as now; but such co-operation would also remove many of the chief causes of international mistrust, and enable much of these budgets to be diverted to happier uses.

Furthermore, their whole professional activity contrasts strongly both in method and success with the military method of settling international problems. The military method is inherently illdesigned to yield good results. Men of science know that the judgment is warped by bitter passions such as prevail in war, and that difficult problems are best attacked by earnest, dispassionate search after understanding and truth, with prolonged patience and resource; they have therefore a special duty to urge the application of these methods to international problems. To attempt to solve the problems by military force, or the threat of it, is to hazard our whole wellbeing, with no certainty that the better cause will 
prevail or the best solution be arrived at : on the contrary, with the certainty that whatever side gains the victory, those who bear the sufferingnowadays the majority of the people-will never reap a reward that will compensate them for their travail and sorrow.

Medical men form a group among scientific workers who have particular reason to hate war and to seek after peace: the wholesale maiming, poisoning and starvation involved in war is in extremest contrast with their lifework for the maintenance of health and the alleviation of human suffering. A campaign to arouse the interest of the medical profession in the promotion of peace has lately been launched, with much devoted work and considerable success: similar efforts have been in progress at Cambridge, Oxford and elsewhere, among scientific workers of other kinds. During the recent National Peace Congress in London, among the several Commissions which considered special aspects of the peace question was one on science and medicine, reference to the proceedings of which appears elsewhere in this issue (p. 993). It is hoped that, as a result of the meetings of this Commission, local groups of scientific workers will be formed in many other places, for the promotion of peace by study, research and propaganda.

We do not overlook the fact that urgent reasons can be given in favour of the present British rearmament, or that there is little likelihood that our vast military preparations will be devoted to selfish aggression. But it cannot be denied that a Europe armed to the teeth will be an unstable Europe, living under the shadow of fear that some spark may produce a disastrous conflagration. What we suggest is that some part of this great effort and expenditure on rearmament would be more fruitful for the peace of Europe and the world, if employed in other ways. The greater part of that expenditure might, indeed, be saved by a more active policy of international co-operation and appeasement.

The main argument against such proposals is that our very safety is threatened by other wellarmed nations, so that rearmament is essential for the defence of our lives and ideals. We know ourselves that our intentions are wholly nonaggressive, but can we expect the rest of Europe to welcome a pax britannica, imposed on 'the lesser breeds' by means of our great national wealth? Surely the only kind of peace likely to endure in Europe is one that is corporately maintained by the community of European nations, whose instrument of co-operation is ready at hand in the League of Nations. The best means to achieve this cannot now be discussed here, but a determined effort, and indeed lead, in this direction seems incumbent on the British Government to assist movements for the promotion of international peace and thus avoid the impression that recent activities are solely concerned with military measures for national defence in case of war.

\section{Science and Social Responsibility}

\section{What Science Stands For}

By Sir John Boyd Orr, Prof. A. V. Hill, Prof. J. C. Philip, Sir Richard Gregory, Sir A. Daniel Hall, Prof. Lancelot Hogben. Pp. 132. (London: George Allen and Unwin, Ltd., 1937.) 5s. net.

\footnotetext{
THE future historian of science will not fail to chronicle that the early part of the twentieth century was notable for the gradual emergence of a social conscience among scientific men, which, he will aver, was greatly stimulated by the mis-use of certain scientific discoveries for inhuman ends (for example, poison gas against civilians), and by the recognition that extending application of science to industry did not appreciably improve the status or the prospects of the working classes.
}

The effects of the so-called impact of science upon social life have for long been made prominent in the columns of NATURE, but it is only of late that they have engaged general attention, for example, at recent meetings of the British Association. Incidentally, the word 'impact' seems ill-chosen, for science has been penetrating, not merely impinging on, the material social fabric for at least a century. At last year's meeting in Blackpool, some notable addresses were given on this theme, of which five are reproduced in the volume before us. Covering as they do a diversity of subjects, the choice of an apt title could not have been an easy one; hence the use of the woolly preposition-verb 'stand for'. If the question implicit in the title had been put to T. H. Huxley, his reply would have been immediate: "For 